\title{
The School Principals' Strategies for Effective School Development in Primary Schools in Bulango Timur, Gorontalo
}

\author{
Novianty Djafri a, Risnawati R. Ibrahim a
}

\begin{abstract}
This study aims (1) to describe strategies of the school principals of primary schools in Bulango Timur, in accordance with the schools' visions and missions; (2) to apply leadership professionals; (3) to reform for more conducive school environment; and (4) to build partnership between the school and students' parents. This research used the descriptive quantitative method with questionnaire and documentation to obtain the data. The result shows that (1) the accordance between the school principals with the schools' vision is categorized as good, with the percentage of 79.53 percent. Moreover, (2) the school principals' professional leadership is categorized as good, with a score of 82.63 percent. Furthermore, (3) the school principals' management for a conducive school environment scored an overall 82.21 percent in the good category, and (4) the principals' partnership with the students' parents scores a total percentage of 80.32 percent, being in good category.
\end{abstract}

Keywords: $\quad$ strategies, effective school development

\section{INTRODUCTION}

Strategy is a set of fundamental decisions and actions designed by the board of management to be implemented in every aspect of an organization to achieve the organization's objectives [1]. A school, as a formal educational institution, is expected to produce creative, innovative, and independent human being, possessing features of progressive mindset, wisdom, and responsibility. Moreover, a school principal is the top of school organizational system hierarchy, since it is a complex and unique duty to perform.

Mulyasa [2] argues that a school principal plays a critical role in the implementation of the school's visions and programs, including decision-making attempts. In making decisions, it is significant for a principal to consider for strategies, by taking the school environment into account, for the school environment is dynamic. Thus it needs different alternatives to tackle particular problems. Moreover, Siagian [3] declares that it is crucial for a school principal to involve the contribution of teachers to provide feedbacks and alternatives for a proper decision-making to achieve the school objective effectively.

The result of preliminary research in primary schools in Bulango Timur district, Bone Bolango regency, Gorontalo province shows that the school principals still lack skill regarding strategies of effective school development. The research discovered critical issues in the primary schools, i.e.

1. Implementation of the schools' vision and mission

The principals failed to actualize the school's vision and mission as expected since there are particular groups of students who struggled to reach the minimum standard of learning mastery and thus unable to progress to the next grade. This situation urged the principals and the teachers to address and resolve the contributing factors.

2. Professional leadership

The observation found out that the there was a gap of quality between primary schools in Bulango Timur district. There are only two from four primary schools in Bulango Timur which possess A-rank accreditation from the Accreditation Board. Henceforth, to minimize the gap, the school principals need to enhance their quality for them to acquire accreditation.

3. Conducive school environment

It is crucial for the school principals and the stakeholders to strive for an encouraging and supportive atmosphere in the school, for such an atmosphere contributes significantly to the students' learning process. Furthermore, the availability of adequate learning resources must be taken into consideration by the principals to create a proper vessel for the students to learn optimally.

4. Partnership between the schools, students' parents, and the community 
An effective partnership with students' parents and the community is indispensable for school to develop as an attempt of ensuring the quality of learning resources to achieve the expected output [4]. Ultimately, as the top of school hierarchy, a school principal is demanded to develop an effective performance and employ proper strategies to boost the school quality.

\section{LITERATURE REVIEW}

\subsection{The school principals' strategies for effective school development}

The strategy of a school principal is a part of the plan as a policy applied by the principal to adapt to the school environment, as an attempt of actualizing the quality of learning process. Moreover, it is an integrated plan which connects organizational strategy with environmental challenges and designed for ensuring that one can achieve organizational objectives with proper execution. Moreover, [1] views strategy from a military perspective; that it is an attempt of utilizing the whole military resources to win a war. A skilled strategist will consider all the aspects of his army, e.g. each soldier's ability, the number of the army, and their motivation of winning.

Furthermore, Wahyudi [5] denotes that a principal needs to excel not only in conceptual duties, (e.g. planning, organizing, problem-solving, and building partnership with the parents) but also in technical duties, such as understanding and applying methods of knowledge, finance, reporting, scheduling, and maintenance. Meanwhile, Wahjosumidjo [6] asserts that a school principal is a functional staff teacher assigned to lead a school. As mentioned previously, the principal's duties are related to issues of administration and supervision; therefore, it is necessary for the principal to possess adequate skills of planning, organizing, employing, controlling, representing, and directing strategically and tactically to accomplish the targets. On top of that, in the selection process of a principal, the management board needs to set a benchmark for the administrative and supervision aspects of each candidate as a requirement to filter the best candidate to lead a school.

Grounding to the previous statements, a principal is a teacher with the capability to lead all the school resources. A principal plays a significant role to lead the future of a school to achieve the expected outcome.

\subsection{Effective School Development}

Supardi [7] emphasizes that an effective school possess two dimensions, i.e. quality and equity. The dimension of quality refers to the efforts in improving students' achievement; on the other hand, equity means that a school must not differentiate students based on their economy level. On top of that, an effective school is without question capable of enhancing students' academic achievement to compete with other schools. Hoy and Ferguson [in 7] argue that an effective school is supposed to produce numbers of outstanding graduates, manage resources wisely, be able to cope with internal and external challenges, and seek to achieve satisfaction within the school.

Based on the statements, it is deduced that an effective school is expected to produce high rate of students' academic achievement, utilize resources considerably, capable to develop an atmosphere to support the learning activity, strive for quality learning process, be able to achieve satisfaction within the school community, and manage to produce significant output to the environment.

An effective school development is essential for better output quality. A school needs to actualize its vision and mission, professional leadership, a conducive school environment, and partnership between school, parents, and the community in order attain the parameter.

1. Vision and mission

Vision is a set of philosophical aims by an organization as a final destination to be achieved by the organization, and as a perspective of the organization in the future. Meanwhile, the mission is an act of setting short-term organizational objectives (one - three years ahead). Wibisono [8] defines vision as a set of sentences to declare future goals of an organization. To put it another way, vision is a 'want to be' statement of an organization. On top of that, vision is essential for the organization to ensure that it is on the right track to achieve long-term success. It is a long-term perspective to be actualized to maintain the organization's existence and innovation, and a description of the future extent desired by the organization.

Furthermore, Wibisono [8] describes mission as targets and reasons which lead and provide scope for the organization to achieve its vision. Essentially, the mission is an informal way to declare the future extent desired and as phases of actions to actualize the organization's vision.

Wibisono [8] further mentions steps of setting missions by an organization, i.e. a) brainstorming for 
words that describe the organization, b) setting priority and focus on the essential words, c) combining the priority words into a sentence or paragraph describing the organization's mission, d) reforming the sentences to create proper sentence arrangement. Moreover, according to Wibisono, [8] aims of a mission is to socialize the reasons of the establishment of an organization to the stakeholders inside and outside the organization. It is supposed that a manager is capable of leading the subordinates to advance the organization to achieve the objectives.

Therefore, it is deduced from the previous theories that vision is a perspective of an organization towards the future goals. There are two key aspects of vision, which is form and substance aspect. An aspect of form involves the language of vision that describes a situation or an outcome. On the other hand, the essence of substance aspect is a description of desired targets and objectives. Moreover, the language of mission describes important duties to perform to achieve the vision.

\section{Professional leadership}

Professional leadership is an indispensable ability for a leader of how to lead the subordinates to progress as expected to achieve the missions set. The progression of the subordinates is obliged to refer to the organization objectives, not to reach the leader's personal desire, since the leader is in spite a part of the organization. A progression is not a camouflage of the leader's target, and it is not only a symbol of position, but it also acts as the legitimacy of the leader's power.

Furthermore, Supardi [7] asserts that a school principal is expected to master general and specific competencies of a professional leader. The principal has a role as leader, manager, and teacher. The type of leadership to be applied is tailored to the conditions and situations encountered in each institution, either it is transactional, transformational, visionary, or a combination of two or all three features.

From the previous statements, it is asserted that professional leadership is the competence of influencing others, directing subordinates' behavior, and possession of special skills in a particular field to achieve organizational objectives. Moreover, it is vital for a professional leader to have features of integrity, intellectuality, intelligence, skill, the capability to control and influence people, willingness to learn and be ready to be assigned to any location.

3. Conducive school environment

School environment, for instance, the physical condition of a school, supporting media in the classroom, teachers, administration staffs, and schoolmates, plays a significant role in contributing to a student's motivation. Slameto [9] points out key aspects of school environment which influence learning activity, i.e. teaching method, curriculum, teacher-student relationship, the relationship between students, school discipline, learning material and duration, minimum mastery standard, the condition of school building, learning method, and homework. A conducive school environment is a supportive atmosphere which encourages the learning activity for optimal result. The principal and teachers need to strive maximally to create and maintain conducive school environment for an effective and efficient students' development to attain the school objectives.

Grounding to the theories, this study concludes that a conducive school environment is the key to success in the management of learning process; therefore, teachers are undoubtedly required to be professional in managing the classroom to create and maintain conducive learning atmosphere within the classroom.

4. Partnership between school, parents, and community

The term 'partnership' is derived from 'partner' which refers to work mate (Widodo, 2002, p.441). Given that, the term 'partnership' is translated as cooperation between parties. Hoetomo (2005, p.336) emphasizes that partnership between the school and the community be conducted to develop the school. One cannot separate a school from the surrounding community since both parties are mutual to each other. A school is a formal institution assigned to educate, train, and nurture young generations to be influential in the future, while a community surrounding the school is the vessel where the generation grows. On top of that, in building a partnership, a school needs to take principles of accountability and independence into account. Moreover, regarding attempts to develop independence, Grant explicitly suggests that once partnership between parties is built, every member from both parties needs to stay neutral, particularly concerning on political affairs. It is also emphasized that financial independence is essential for the partnership, and the parties are obliged to maintain the principle of accountability, despite supports offered by other parties.

By the theories, this study deduces that schoolcommunity partnership is significant for the school development and is developed by the school committee, meeting between school and the community, and consultations. 


\section{RESEARCH METHOD}

The study was conducted for three months and took place in primary schools in Bulango Timur district, Bone Bolango regency, Gorontalo province. It is a descriptive quantitative research, which by Sugiyono [11] is conducted to describe the school principals' strategies in developing for an efficient school in primary schools in Bulango Timur district. On top of that, the subject of the research comprised the whole aspects related to the principals' strategies in developing an effective school. This study engaged and documentation to obtain the data.

\section{DISCUSSION}

\subsection{The principals' implementation of school vision and mission}

There are 10 indicators to be conducted by the principals to strive for a well-implemented school vision and mission, i.e. 1) The principal collaborates with the teachers to set the school vision; 2) a wellarranged vision; 3) a clear formulation of the vision; 4) the principal strive to enhance quality mission; 5) the principal strive to enhance points of mission regarding the students' competence; 6) an efficient and effective implementation of a mission; 7) the principal enhance the mission competence; 8) the principal can develop a supportive school atmosphere; 9) the principal strives for a quality school; 10) the principal strives for excellent human resources.

From the observation, the school principals have scored 79.53 percents of satisfaction indicators regarding the implementation of school vision and mission, hence, being in a good category. Nevertheless, it is undoubtedly necessary for the principals to keep on improving the implementation to produce excellent graduates as the output of the school. Moreover, awards such as widyata charter will be rewarded to the schools with the advanced implementation of school vision and mission; for that reason, it is without question that a principal needs to take the school vision and mission into consideration.

Furthermore, Duke [in 7] points out that vision is influential for a school principal to boost the teaching quality. The notion is echoed by Rahimah [in 7] that the indicator of an effective school is that the school principal is capable of implementing the vision and mission, endowed with high commitment, and encourage for maximum quality and accountable work ethic to the subordinates.

\subsection{Professional Leadership}

There are 10 indicators of professional leadership for the principals to actualize, i.e. 1) the principal's punctuality; 2) the principal obeys the school rules; 3 ) the principal provides examples of good appearance; 4) the principal's responsibility of the school; 5) the principal encourages the teachers to participate in training; 6) the principal guides teachers in developing learning programs, 7) the principal's trust towards the teachers in performing daily tasks; 8) the principal supports the teachers to develop reading habits; 9) the principal conducts a forum discussion to tackle school problems; (10) the principle can communicate openly.

The observation displayed that the principals were able to reach good category in satisfaction percentage of actualization of professional leadership, by scoring 82.63 percent. On top of that, a principal needs to cope well with the teachers, for the teachers contribute the most to the school development. A principal is expected to direct the teachers to develop effective teaching methods for optimal engagement by the students. It is crucial for a principal to guide the teachers frequently to compete with other schools and to encourage the students properly. Furthermore, Sagala [10] declares that a principal is required to possess the competence of a professional teacher. This is to say, as an attempt of implementing effective school development; it is indispensable for a principal to develop a professional leadership.

\subsection{Organization of a conducive school environment}

There are five indicators of a conducive school environment to be implemented by a school principal, namely: 1) a beautifully organized school environment; 2) the existence of park within the school; 3) parking lot arrangement which not disturb learning activities; 4) well-arranged air circulation within the classrooms; and 5) the principal encourages the students to not litter.

The observation result showed that the principals were capable of generating a conducive school environment by scoring 82.21 percents on the satisfaction questionnaire. This echoes the statement that an unconducive school environment might lead to the students' poor concentration during the learning process. Given that, a principal needs to 
encourage the teachers and students to manage school infrastructure effectively to leave the learning process undisturbed. Furthermore, Supardi [7] highlights that a learning process also concerns on the systematical management of school environment which involves infrastructure, facilities, and procedures to be adjusted with the students' need to achieve learning objectives. This is in line with Pipin [in 7] who asserts that a learning process needs to notice several factors to boost learning effectiveness, i.e. the classroom situation, learning resources, media, and learning tools.

\subsection{Developing a partnership between the school and the community}

There are five indicators of a good partnership between school and the community to be achieved by the school principals, i.e. 1) the principal conduct a meeting with the students' parents; 2) the condition in which the parents provide aids to the school; 3 ) the principal cooperates with the parents to enhance school quality; 4) the principal conducts a forum with the school committee to discuss the school financial needs, and 5) the principal discuss about any school activities with the school committee.

The observation showed that the principals were able to develop a good partnership with the community. In the satisfaction questionnaire, the partnership between the schools and the community was at 80.32 percents. Furthermore, the research recommends the principals to improve the partnership between school and parents to achieve the expected objectives. In developing a partnership, the parents' support is also necessary to encourage their children to participate in school events, e.g. Science Olympic and extracurricular events to help to boost the school's competence.

\section{CONCLUSION AND SUGGESTIONS}

The observation result displayed that the principals of primary schools in Bulango District, Bone Bolango regency were able to fulfill the indicators; that: 1) the principals were capable of implementing the schools' vision and mission, with 82.21 percents in satisfaction questionnaire; 2) the school principals were able to actualize professional leadership by scoring 82.63 percents in satisfaction questionnaire; 3) The principals were able to generate conducive school environment by scoring 82.21 percents in the satisfaction questionnaire; and 4) the principals have developed good partnership with the community, with score of 80.32 percents in satisfaction questionnaire.

Furthermore, the research suggests that: 1) the school principals still need to develop the management within the school to achieve the school vision and mission; 2) the school principals are required to actualize the features of professional leadership, to be responsible for their duties in order to compete with other schools; 3 ) it is necessary for the principals to be observant to the teachers in generating conducive school environment, and 4) the principals are obliged to keep developing mutual partnership with the parents and encourage the parents to motivate their children to study.

\section{REFERENCES}

[1] Sanjaya, Wina. 2006. Strategi Pembelajaran Berorientasi Standar Proses Pendidikan. Perdana Media Group: Jakarta

[2] Mulyasa, E, 2013. Manajemen \& Kepemimpinan Kepala Sekolah. PT Bumi Aksarana: Jakarta

[3] Siagian, Sondang P. 2015. Manajemen Peningkatan Mutu Berbasis Sekolah. Cv Cifta Cekas Grafika: Bandung

[4] Semiawan, R. Conny. 2008. Belajar dan Pembelajaran Prasekolah dan Sekolah Dasar. PT. Indeks: Jakarta.

[5] Wahyudi. 2009. Kepemimpinan Kepala Sekolah Dalam Organisasi Pembelajaran (Learning Oragnization). Alfabeta: Bandung

[6] Wahjosumidjo, 2007, Kepemimpinan Kepala Sekolah, PT Raja Grafindo Persada Jakarta.

[7] Supardi. 2013. Sekolah Efektif. PT Raja Grafindo Persada: Jakarta.

[8] Wibisono, Dermawan. 2006. Manajemen Kinerja. Erlangga: Bandung

[9] Slameto. (2003). Belajar dan Faktor-Faktor YangMempengaruhinya. Salatiga IKIP UKSW.

[10] Sagala, Syaiful, 2013. Kemampunan Professional Guru dan Tenaga Kependidikan. Alfa Beta cv: Bandung.

[11] Sugiyono. 2013. Metode Penelitian Pendidikan. ALFABETA: Bandung

[12] Asmani, Jamal. 2012. Tips Menjadi Kepala Sekolah Professional. Sampangan: Diva Press.

[13] Sudrajat, Akhmad. 2008. Pengertian Pendektan Strategi, Metode, Teknik Dan Model Pembelajaran. Sinar Baru Algensindo: Bandung. 
